\title{
Transient Expression of Biologically Active Anti-rabies Virus Monoclonal Antibody in Tobacco Leaves
}

\author{
Mona Shafaghi ${ }^{1 \dagger}$, Somayeh Maktoobian ${ }^{1 \dagger}$, Rahimeh Rasouli ${ }^{2}$, Nader Howaizi ${ }^{3}$, Hamideh Ofoghi ${ }^{4}$, \\ Parastoo Ehsani ${ }^{1^{*}}$ \\ ${ }^{1}$ Department of Molecular Biology, Pasteur Institute of Iran, Tehran, Iran \\ ${ }^{2}$ Department of Medical Nanotechnology, School of Medicine, International Campus, Tehran University of Medical Sciences, Tehran, Iran \\ ${ }^{3}$ WHO Collaborating Centre for Reference and Research on Rabies, Pasteur Institute of Iran, Tehran, Iran \\ ${ }^{4}$ Department of Biotechnology, Iranian Research Organization for Science and Technology (IROST), Tehran, Iran
}

\begin{abstract}
"Corresponding author: Parastoo Ehsani, Department of Molecular Biology, Pasteur Institute of Iran, Tehran, Iran. Tel: +98 2164112219, Fax: +98 21 64112803, E- mail: p_ehsani@pasteur.ac.ir

${ }^{\dagger}$ Mona Shafaghi, Somayeh Maktoobian contributed equally to this work.
\end{abstract}

Received: 24 Dec. 2016; $\quad$ Revised: 2 Oct. 2017; Accepted: 2 Mar. 2018; Published online: 18 Apr. 2018

\begin{abstract}
Background: Rabies virus is a neurotropic virus that causes fatal, but, a preventable disease in mammals. Administration of rabies immunoglobulin (RIG) is essential for the post-exposure of the prophylaxis to prevent the disease. However, replacement of polyclonal RIGs with alternative monoclonal antibodies (MAbs) that are capable of neutralizing rabies virus has been recommended.

Objectives: Here, we have investigated the transient expression of the full-size human MAb against rabies virus glycoprotein; the MAb SO57 in the tobacco plants using vacuum agro-infiltration. Previously, stably transformed plants expressing the MAb have been reported.

Materials and Methods: In this study three vectors carrying the codon-optimized genes for the heavy or light chain and p19 silencing-suppressor were constructed. These vectors were co-infiltrated into Nicotiana tabacum leaves and the transgenes were expressed.

Results: Dot blot, Western blotting, ELISA, and in vitro neutralization assays of the plant extracts showed that the human MAb could assemble in tobacco leaves and was able to neutralize rabies virus.

Conclusions: This study is the first report of transient expression of human MAb SO57 gene in tobacco plant within a few days after vacuum agro-infiltration.

Keywords: Agro-infiltration, Human anti-rabies virus monoclonal antibody, Transient expression, Tobacco plant
\end{abstract}

\section{Background}

Rabies is a fatal zoonotic viral disease caused by RNA viruses of Lyssavirus genus; a member of Rhabdoviridae family. It is usually transmitted via bite or scratch of an infected animal and causes 55,000 fatalities worldwide each year $(1,2)$. This lethal infection can be prevented by the post-exposure prophylaxis (PEP) consisting of the wound cleansing, vaccination, and infiltration of the rabies immunoglobulin (RIG). After exposure, RIG should be administered as soon as possible in order to neutralize the virus before the induction of immune response by vaccination $(3,4)$. Currently, human (HRIG) or equine RIG (ERIG) derived from immunized humans or horses is used, but the risk of adverse reactions associated with the ERIG and the high cost of HRIG makes replacement of the polyclonal RIGs with an alternative product desirable. The World Health Organization (WHO) has recommended the use of rabies virus neutralizing monoclonal antibodies (MAbs) as an efficient and economical replacement of RIGs for PEP (5-8). One of the MAbs directed to the rabies virus glycoprotein, as the major determinant of the virus neurovirulence, was described by Prosniak et al. This human monoclonal antibody (SO57) was selected among the three others which displayed a potent neutralization effect against different rabies virus strains $(9,10)$.

Copyright (C 2017 The Author(s); Published by National Institute of Genetic Engineering and Biotechnology. This is an open access article, distributed under the terms of the Creative Commons Attribution-NonCommercial 4.0 International License (http://creativecommons.org/licenses/ by-nc/4.0/) which permits others to copy and redistribute material just in noncommercial usages, provided the original work is properly cited. 
In recent years, MAbs have been produced using a variety of host systems, such as bacteria, yeast, mammalian cells, animals, and plants (11). Producing MAbs in plants has many economic and safety benefits including reduction of cost, lack of contamination with human and animal pathogens, and ease of scaling-up $(12,13)$. Over the past two decades, various engineered antibodies have been expressed successfully in transgenic plants (1418 ) including human anti-rabies MAb SO57 in both transgenic tobacco plants (13) and tobacco cell culture (19). Transient expression technology for production of the pharmaceutical proteins in plants offers several advantages over the stable transformation including ease of genetic manipulation, low cost, high expression levels, and rapid scalability (20-22); resulting in its use for production of several fully functional MAbs such as anti-Ebola MAb cocktail, anti-HIV Mab, as well as chimeric anti-rabies MAb 62-71-3 (21, 23-25).

Post-transcriptional gene silencing is one of the major drawbacks of the plants' expression systems and as a solution co-expression of RNA-silencing suppressors has been recommended to enhance the level and durability of the transient expression in the plants (26). One of the inhibitors used for this purpose is p19 viral suppressor from Tomato Bushy Stunt virus (TBSV) and its use in some cases has been shown to improve recombinant protein expression levels by 50 fold $(26,27)$.

In this study, for producing human anti-rabies MAb SO57, agroinfiltration technique was employed as a preferred technique for transient expression in tobacco leaves $(22,28)$. We used codon adaptation index of the tobacco plant to optimize antibody-coding genes (i.e., heavy and light chains) and utilized the RNA silencing suppressor strategy to enhance the expression of the cloned genes. The effect of the RNA silencing on the expression was monitored by using green fluorescent protein (GFP) as the reporter gene. The expressed plantibodies were analyzed for antigen-binding and rabies virus neutralization activity, by the Western blot, ELISA, and Rapid Fluorescent Focus Inhibition Test (RFFIT), and compared with the commercial HRIG. To our knowledge, this is the first report of the transient expression of human MAb SO57 gene in the tobacco plant.

\section{Objectives}

The aim of this study was to transiently express the fulllength human anti-rabies virus MAb SO57 in tobacco (Nicotiana tabacum) leaves using vacuum agroinfiltration.

\section{Materials and Methods}

\subsection{Construction of Expression Vectors}

The coding sequences of the monoclonal antibody SO57 heavy chain (HC; Accession No. AY172957), light chain (LC; Accession No. AY172960) (9), and the $\mathrm{p} 19$ gene silencing suppressor of TBSV (Accession No. M21958) (26) were used in this study. The HC and LC coding sequences were optimized according to the tobacco codon index and synthesized (Biomatik, Canada). Modifications of the antibody genes were included the replacement of unfavorable codons, removal of the destabilizing structures, and the reduction of the final GC content. In addition, Kozak sequence was added to the N-terminal (29), the ER retention signal (KDEL) to the C-terminal (30), the and appropriate restriction sites to both ends of the genes. The synthesized HC or LC, plus amino- and carboxyterminal modifications were cloned into the NcoI/BstEII or XhoI sites of the plant binary vector pCAMBIA1304 under the control of CaMV $35 \mathrm{~S}$ promoter, creating the recombinant plasmids Hea-Pcambia and Li-Pcambia, respectively. The p19 gene (synthesized by Biomatik, Canada) was also cloned into the NcoI/BstEII-digested pCAMBIA1304 vector, producing the construct p19Pcambia. The maps of the T-DNA regions of the recombinant plasmids are shown in Figure 1. Cloning steps were carried out according to standard methods (31) and were further confirmed by the restriction enzyme digestion, colony PCR, and DNA sequencing.

\subsection{Agroinfiltration of the Nicotiana Tabacum Leaves}

The competent Agrobacterium tumefaciens strain GV3101 (provided by Dr. Salmanian, National Institute of Genetic Engineering and Biotechnology of Iran was transformed with the recombinant plasmids purified from $E$. coli using calcium chloride transformation protocol (32) and selected in the presence of $30 \mu \mathrm{g} \cdot \mathrm{mL}^{-1}$ kanamycin and $10 \mu \mathrm{g} \cdot \mathrm{mL}^{-1}$ gentamicin. The transformations were confirmed by colony PCR. Agrobacterium suspensions were prepared three days prior to the agroinfiltration by growing the bacteria in the liquid Luria-Bertani medium (Merck, Germany) containing antibiotics at $28{ }^{\circ} \mathrm{C}$ overnight on a shaker. The fresh medium was inoculated with the $\mathrm{O} / \mathrm{N}$ culture at a ratio of $1: 10$ $\mathrm{v} / \mathrm{v}$ and further incubated for $3 \mathrm{~h}$ at $28{ }^{\circ} \mathrm{C}$. Finally, the bacteria were centrifuged, resuspended to an optical density (OD) of 1.0 at $600 \mathrm{~nm}$ in the solution of $10 \mathrm{mM} \mathrm{MgCl}, 10 \mathrm{mM}$ MES (pH 5.5) and $2 \%$ $(\mathrm{w} / \mathrm{v})$ sucrose, and induced for 90 min with $200 \mu \mathrm{M}$ acetosyringone (Sigma, USA) before the infiltration 
Hea-Pcambia

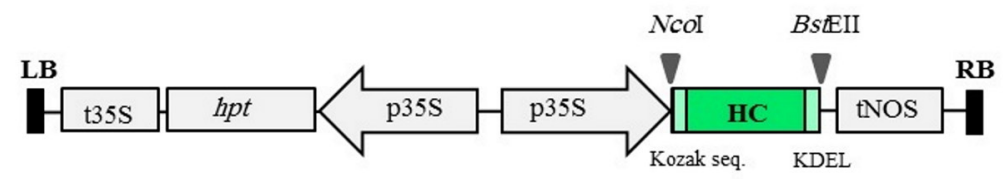

Li-Pcambia

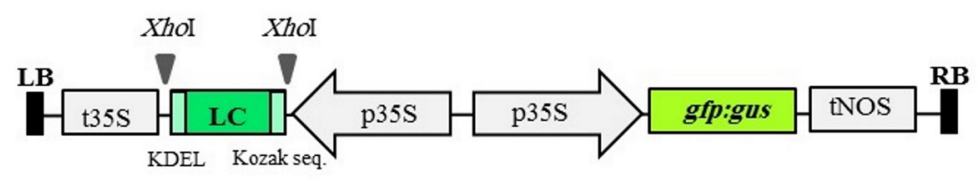

p19-Pcambia

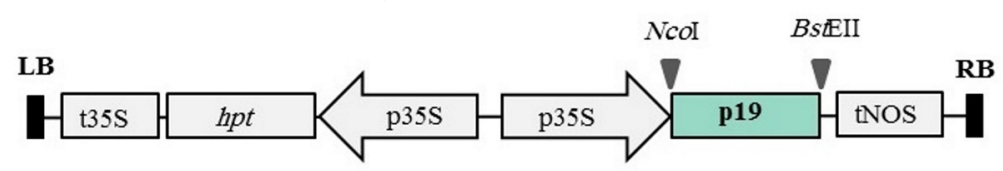

Figure 1. Schematic representation of the T-DNA region of Hea-, Li- and p19-Pcambia vectors used for transient expression. LB and RB: left and right borders; $\mathrm{p} 35 \mathrm{~S}$ and $\mathrm{t35S}$ : Cauliflower Mosaic Virus (CaMV) $35 \mathrm{~S}$ promoter and terminater; $h p t$ : hygromycin resistance; HC and LC: codon-optimized heavy and light chains genes; tNOS: nopaline synthase terminator; $g f p$ : gus: green fluorescent protein gene fused to $\beta$-glucuronidase gene; p19: p19 gene silencing suppressor of TBSV; NcoI, BstEII and XhoI: restriction enzyme sites; Kozak seq.: Kozak sequence; KDEL: ER retention signal.

(33). To the suspension, Tween-20 was added to a final concentration of $0.01 \%$ and the suspensions were used for vacuum agroinfiltration.

The young leaves of the tobacco (Nicotiana tabacum var. Samsun provided by Dr. Rajabi Memari, Shahid Chamran University of Ahvaz, Iran) were scratched with a needle and vacuum-agroinfiltrated twice for $2 \mathrm{~min}$ at 0.5 mbar. Li-pcambia carrying GFP construct was used to demonstrate the effect of p19 on expression efficiency. The leaves were exposed to the UV light $(365 \mathrm{~nm})$ at the day 4 of post infiltration (dpi) using EpiChemi II (EC2) darkroom system from UVP Bioimaging Systems (UVP, Inc.). The Agrobacterium harboring p19 vector was co-infiltrated with Agrobacteria carrying either Hea-Pcambia or LiPcambia or mixture to a final $\mathrm{OD}_{600}$ of 1.0 for each. The agroinfiltrated leaves were maintained for 4 days at 24 ${ }^{\circ} \mathrm{C}$ with 16 hours of light.

\subsection{Protein Extraction}

The agro-infiltrated tobacco leaves were frozen in the liquid nitrogen and homogenized in the extraction buffer containing $200 \mathrm{mM}$ Tris- $\mathrm{HCl}$ (pH 8.0), 100 $\mathrm{mM} \mathrm{NaCl}, 400 \mathrm{mM}$ Sucrose, $10 \mathrm{mM}$ EDTA, $14 \mathrm{mM}$ $\beta$-ME, $0.05 \%$ Tween-20, and $1 \mathrm{mM}$ PMSF ( $1 \mathrm{~mL}$ per gram of leaf powder). After centrifugation twice at $12396 \times \mathrm{g}$ for $30 \mathrm{~min}$ at $4{ }^{\circ} \mathrm{C}$, the supernatant was collected or passed through a $0.4 \mu \mathrm{m}$ filter and the total protein concentration was measured (34).

\subsection{Purification of Recombinant MAb}

Isolation of the MAb from protein extracts was performed by protein An affinity chromatography (Protein A MagBeads GenScript, USA). The mixed filtered fraction with magnetic beads was incubated at $4{ }^{\circ} \mathrm{C}$ on a rocker for $1 \mathrm{~h}$ and subsequently, the beads were packed into a column and washed twice with binding/wash buffer $\left(20 \mathrm{mM} \mathrm{Na} \mathrm{HPO}_{4}, 0.15 \mathrm{M} \mathrm{NaCl}\right.$, $\mathrm{pH}$ 7.0). The bound MAbs were eluted with elution buffer $(0.1 \mathrm{M}$ glycine, $\mathrm{pH} 2.5)$ and the $\mathrm{pH}$ of the eluate was neutralized with $1 \mathrm{M}$ Tris, $\mathrm{pH}$ 8.5. The elution steps were repeated twice.

\subsection{Dot Blot Analysis}

The plant extracts of the experimental samples, negative control $(500,100$, or $50 \mu \mathrm{g})$, and human serum that were obtained from a volunteer $(1 \mu \mathrm{L}$ contains $29 \mu \mathrm{g}$ globulin) were placed on the nitrocellulose membrane (Schleider and Schull, Germany). The membrane was blocked with blocking buffer containing 1X PBS, $0.1 \%$ Tween-20, and 1\% PVP (Polyvinylpyrrolidone, Sigma USA) for $90 \mathrm{~min}$ at room temperature, and then incubated with HRP conjugated goat anti-human IgGFc fragment (Bethyl, USA) or goat anti-human lambda light chain specific antibodies (Bethyl, USA) diluted in blocking buffer (1:5000 and 1:2000, respectively). Following to the three times of wash, each for $10 \mathrm{~min}$ in PBS containing $0.1 \%$ Tween-20, the bound proteins to the nitrocellulose membrane were detected by the 
addition of DAB (3,3'-diaminobenzidine; Sigma, USA) and $\mathrm{H}_{2} \mathrm{O}_{2}$ (hydrogen peroxide).

\subsection{Western Blot Analysis}

The proteins were resolved on $12 \%$ reducing and $8 \%$ non-reducing SDS-PAGE gel using Laemmli's buffer system (35) and then transferred to PVDF membrane (Immobilon P, Millipore) by semi-dry blotting (BioRad, USA). The blots were processed as described above.

\subsection{Enzyme-Linked Immunosorbent Assay}

The specificity and concentration of the plant-derived $\mathrm{MAb}$ were estimated by ELISA. Briefly, microtiter plates were coated with $1 \mu \mathrm{g} /$ well of the inactivated rabies virus (CVS-11), incubated overnight at $4{ }^{\circ} \mathrm{C}$, and blocked with $1 \%$ bovine serum albumin (BSA) in PBS with $0.05 \%$ Tween-20 (TPBS) for 1 h at room temperature. After several washes with TPBS, the serial dilutions of the plant extracts, starting with 9.4 $\mu \mathrm{g}$ of purified antibody, were added to each well and were incubated at room temperature for $1 \mathrm{~h}$. HRPconjugated anti-human IgG-Fc fragment (1:10000) (Bethyl, USA) was used as secondary antibody and after incubation for $90 \mathrm{~min}$ and three washes with TPBS, the plates were developed by the addition of $100 \mu \mathrm{L}$ of 3, 3, 5, 5-tetra methyl benzidine (TMB) (Bio Biz, Korea) to each well and incubated at room temperature for $30 \mathrm{~min}$. The reaction was stopped by adding $1 \mathrm{M}$ sulfuric acid and the absorbance was read at $450 \mathrm{~nm}$. The concentration of the plant-derived $\mathrm{MAb}$ was determined against the standard curve prepared by applying the commercially available human rabies immunoglobulin (HRIG; Berirab ${ }^{\circledR} \mathrm{P}$, Marburg, Germany).

\subsection{In vitro Neutralization Assay by Rapid Fluorescent} Focus Inhibition Test

Neutralizing activity of the purified MAbs (300 $\mu \mathrm{L}$ ) was estimated using the rapid fluorescent focus inhibition test (RFFIT) (36). Briefly, the diluted purified MAbs were mixed with a constant dose of challenge virus (CVS-11) sufficient to cause infection in $80 \%$ of the cells and the antibody-virus mixture was incubated for $60 \mathrm{~min}$ at $37{ }^{\circ} \mathrm{C}$. After incubation, the mixtures of the antibody and virus was added to the susceptible BSR cells, a clone of baby hamster ovary cells, and after a further $24 \mathrm{~h}$ incubation, the cell monolayer was fixed and stained with fluorescein labeled anti-rabies nucleocapsid conjugate (Bio-Rad, France) and examined under fluorescent microscope.

\section{Results}

4.1. Cloning and Transient Expression of Anti-Rabies MAb in Tobacco

Codon optimization of the antibody genes was achieved by altering $25.5 \%$ and $26.3 \%$ of nucleotides from unmodified sequences of the heavy and light chains genes, respectively. The modifications increased the codon adaptation index (CAI) values to 0.68 compared to those of the non-optimized genes, which were 0.62 (HC) and 0.63 (LC) (Fig. 2A). In addition, the GC content of the $\mathrm{HC}$ and $\mathrm{LC}$ sequences were reduced from 59.24 to 49.60 and from 58.93 to 51.41 , respectively (Fig. 2B).

\subsection{The Enhancement Effect of the P19 on Expression Yield}

The recombinant constructs were evaluated by the restriction analysis prior to the transformation of the Agrobacterium tumefaciens and after transformation by colony PCR which produced a 1445-bp or 743-bp fragment for the $\mathrm{HC}$ and $\mathrm{LC}$ genes, respectively (data not shown). The GFP gene in Li-pcambia T-DNA region was used as the reporter for confirmation of gene transfer and p19 enhancement effect on the gene expression, as well. The obtained results showed that co-infiltration of a 1:1 (OD) mixture of the two GV3101 Agrobacterium populations harboring p19 and $\mathrm{Li}$ (carries GFP) vectors could enhance expression of GFP for up to several orders of the magnitude at the infiltrated area 4 days post infiltration (Fig. 3).

\subsection{Analyses of Transient Expression by Dot and Western Blot Analysis of the Plantibodies}

The initial analyses of the antibody chains' accumulation were performed by the dot blot analysis (Fig. 4). The analysis of the co-agroinfiltrated plant leaves' extract at 4 dpi showed that either the light chain (Li-pcambia Fig. 4 A3) or heavy chain (Hea-Pcambia) (Fig. 4 B3), or both together (Fig. 4 B4) have accumulated in the plants that had been agro-infiltrated with the corresponding Agrobacterium cultures compared to the plants that had not been infiltrated with the recombinant Agrobacterium (Figs. 4 A2 and B2).

The expression of heavy and light chains, as well as the fully assembled MAb, were monitored by Western blotting applying both reducing and non-reducing SDSPAGE four days post infiltration (Fig. 5). Both $\mathrm{HC}$ and LC were identified in the extracts from leaves vacuum co-infiltrated with a mixture of Agrobacteria harboring the $\mathrm{HC}, \mathrm{LC}$, or $\mathrm{p} 19$ constructs. Figure $5 \mathrm{~A}$ shows bands of $\sim 50 \mathrm{kDa}$ and $\sim 25 \mathrm{kDa}$ corresponding to the $\mathrm{HC}$ and 
A

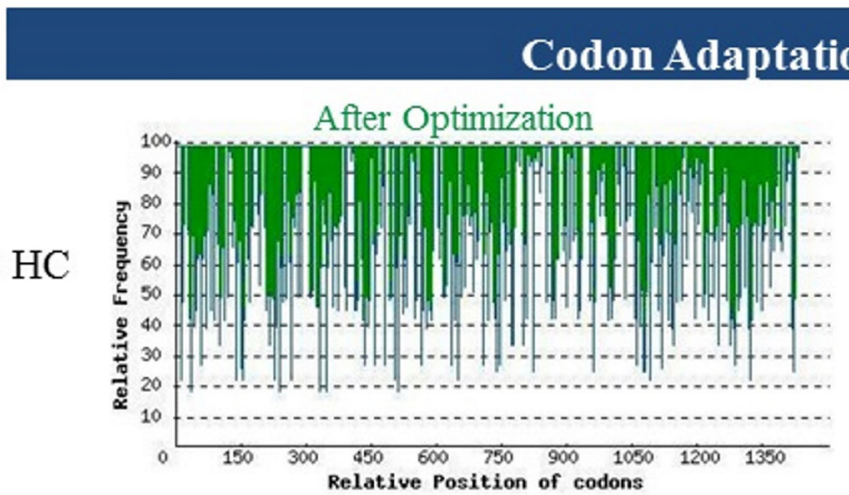

CAI : 0.68

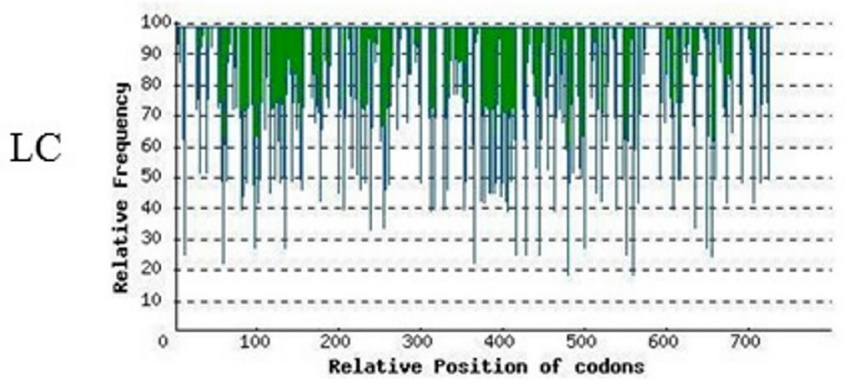

B

CAI : 0.68

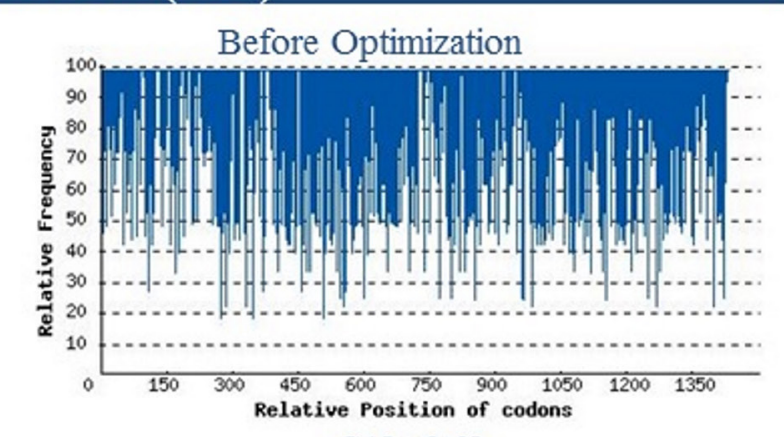

CAI : 0.62

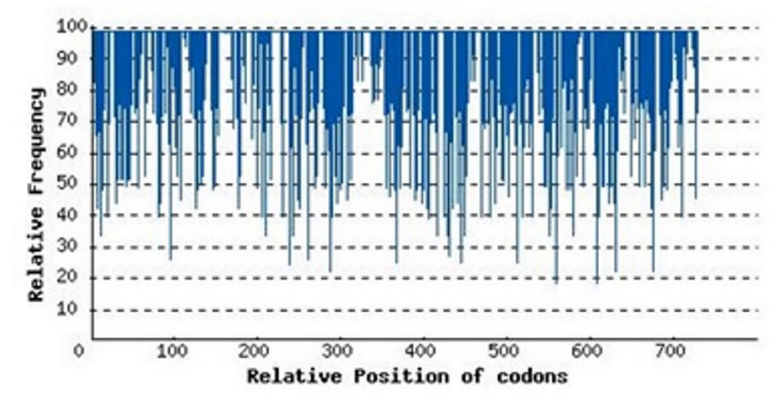

CAI : 0.63

\section{GC Content Adjustment}
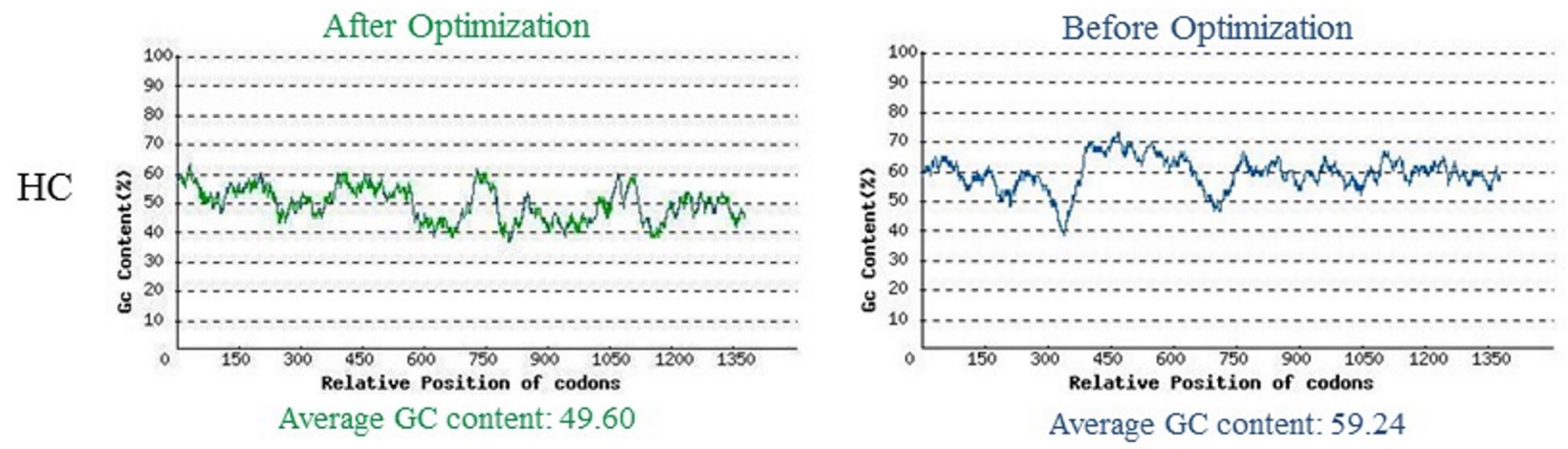

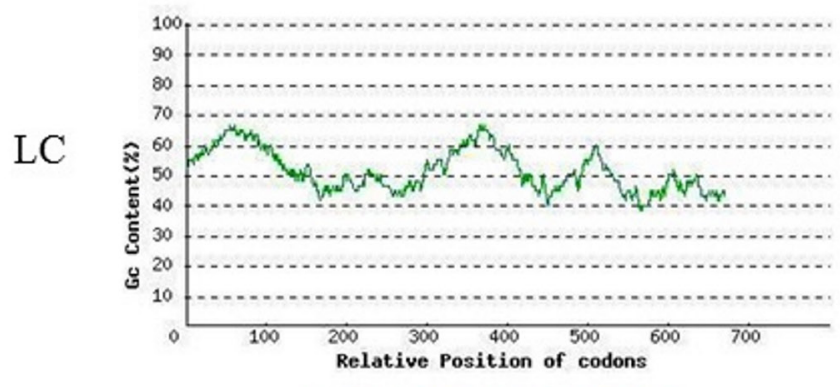

Average GC content: 51.41

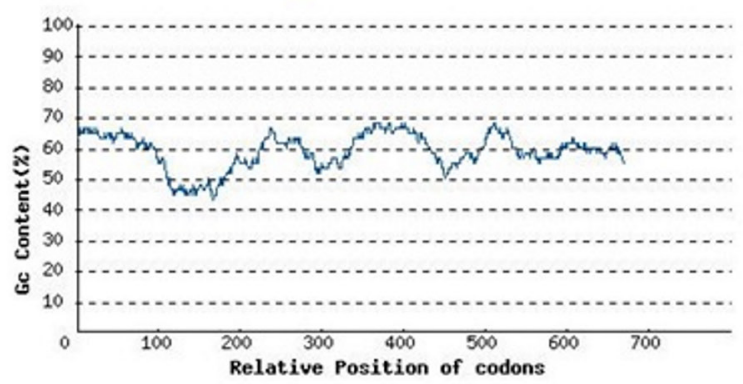

Average GC content: 58.93

Figure 2. The sequence alterations after codon optimization. (A) Codon usage analysis of original and optimized heavy and light chains genes. (B) GC analysis of original and optimized antibody chains genes. 


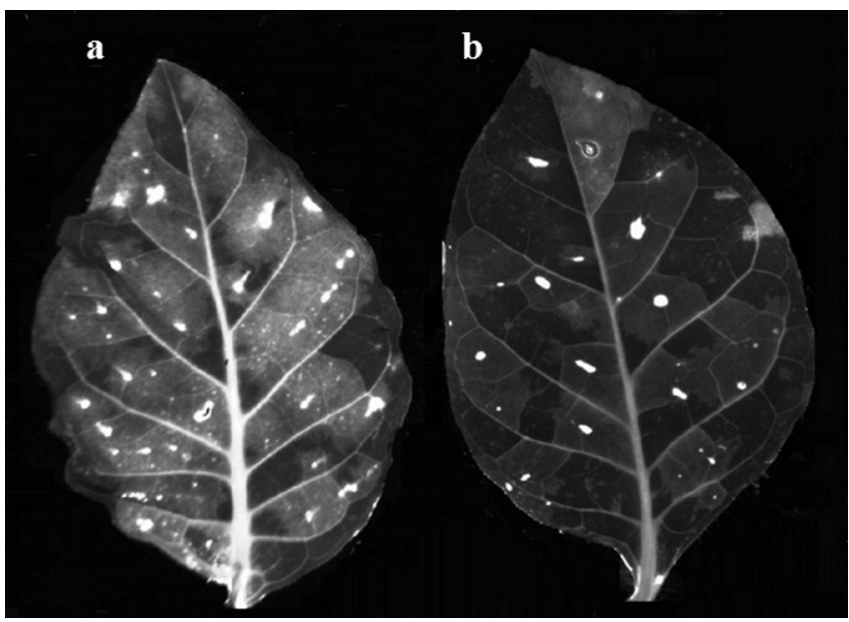

Figure 3. Enhancement effect of p19 construct on transient expression of GFP. Co-agroinfiltration of vector expressing light chain and GFP with (a) and without (b) p19 expression vector.

LC that are not found in the negative control using anti$\mathrm{Fc}$ fragment and lambda light chain specific antibodies under reducing conditions. Under non-reducing conditions, the fully assembled MAb migrated as a major band of $\sim 170 \mathrm{kDa}$ corresponding to the $\mathrm{H}_{2}, \mathrm{~L}_{2}$ heterotetramer (Fig. 5B).
$\mathbf{A}$

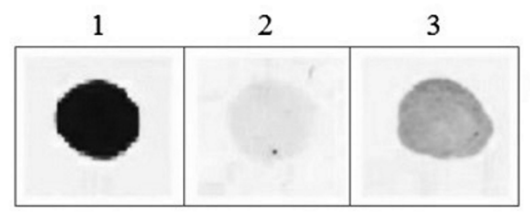

B

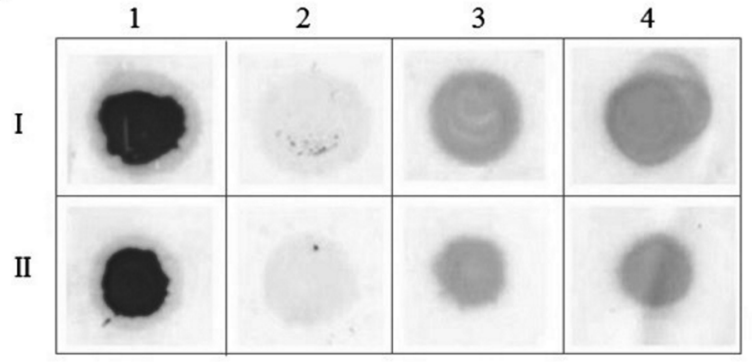

Figure 4. Dot blot analysis of plant extract of coagroinfiltrated leaves (A) 1: human serum. 2: crude extracts from non-agroinfiltrated tobacco leaves $(500 \mu \mathrm{g})$. 3: crude extracts from leaves co-agroinfiltrated with Agrobacteria carrying Li-Pcambia and p19-Pcambia $(500 \mu \mathrm{g})$. (B) Rows I and II correspond to $100 \mu \mathrm{g}$ and $50 \mu \mathrm{g}$ of total soluble protein (TSP), respectively. 1: human serum. 2: non-agroinfiltrated tobacco leaves. 3: plant extracts from leaves co-agroinfiltrated with Agrobacteria containing HeaPcambia and p19-Pcambia vectors. 4: the extracts from vacuum co-agroinfiltrated leaves by Agrobacteria carrying Hea-Pcambia, Li-Pcambia and p19-Pcambia.
A

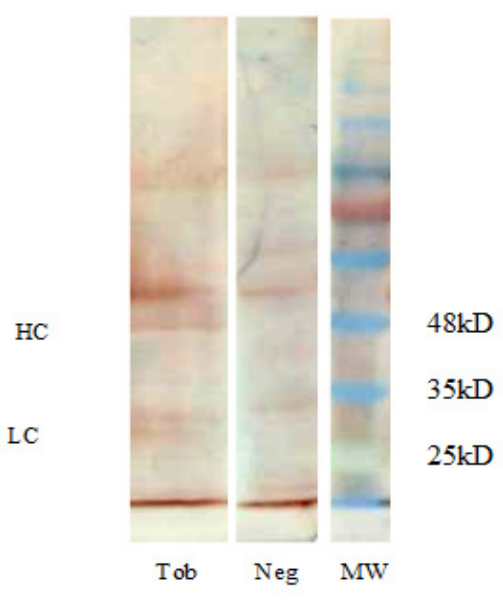

B

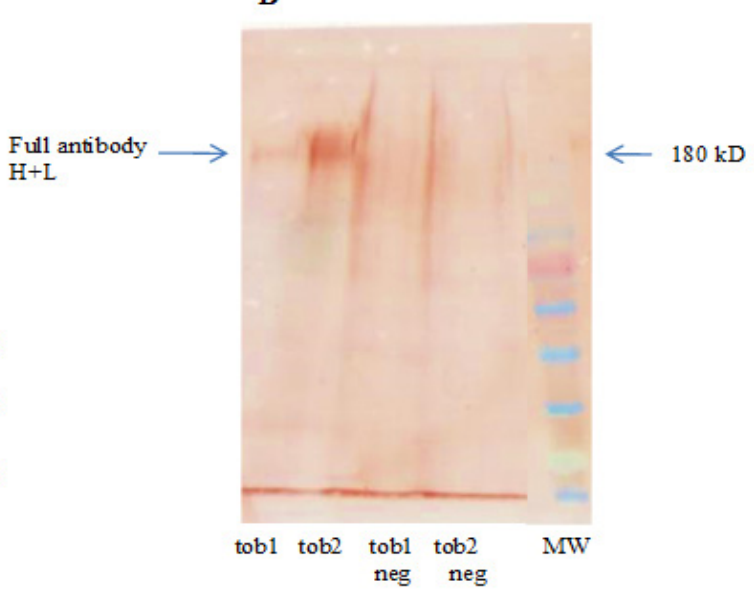

Figure 5. Western blot analysis of plant extract in reducing and non-reducing conditions. (A)) The Analysis in the reducing condition revealed that the bands corresponding to the $\mathrm{HC}(\sim 50 \mathrm{kDa})$ and $\mathrm{LC},(\sim 25 \mathrm{kDa})$ were absent in Neg. lane which contains the non-agroinfiltrated Nicotiana tabacum leaf extract. MW: molecular weight marker. tob: protein extract from co-agroinfiltrated leaves with recombinant Agrobacterium suspensions (32 $\mu \mathrm{g}$ TSP per lane). Neg: extracts from non-agroinfiltrated tobacco leaves (39 $\mu \mathrm{g}$ per lane). (B) Western blot analysis of non-reducing SDS-PAGE presents fully assembled hetero-tetrameric form of MAb in comparison to negative control which migrates around $\sim 170 \mathrm{kDa}$. 1\&2: extracts from co-agroinfiltrated leaves (22 and $32 \mu \mathrm{g}$ TSP per lane, respectively). Tob1neg and tob2neg: extracts from non-agroinfiltrated leaves (about $39 \mu \mathrm{g}$ per lane). MW: molecular weight marker. 


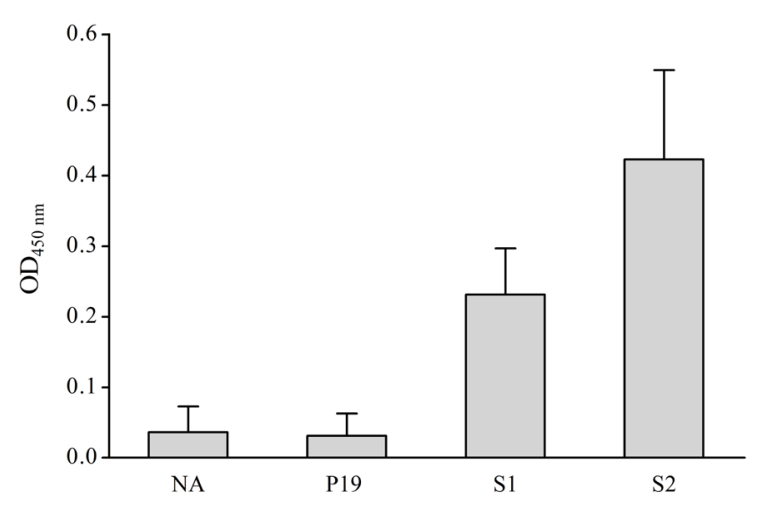

Figure 6. ELISA analysis of self-assembled MAb SO57 in agro-infiltrated tobacco leaves. At 4 days after agroinfiltration, $9.4 \mu \mathrm{g} /$ well of the leaf extracts was applied on ELISA plates coated with rabies virus. NA: protein extracts from non-agroinfiltrated leaves (negative control). P19: extracts from plants agroinfiltrated with p19-containing Agrobacterium (negative control). S1 and S2: samples obtained at two different agroinfiltrations of tobacco leaves with Agrobacteria containing antibody chains and p19 expression vectors. The values are the average OD derived from two replicates, with standard deviations.

\subsection{Analysis of Recombinant MAb Production by ELISA}

Applying ELISA technique, it was shown that the levels of transiently expressed MAb in the two preparations of tobacco leaves were $0.014-0.019 \%$ of TSP, using HRIG standard curve. Results confirmed that the assembled plant antibodies could recognize CVS-11 rabies virus similar to that of the commercial HRIG (Fig. 6). As shown in Figure 6, the average optical density (OD) reading of the plant samples expressing the fully assembled antibody (S1 and S2) was two- to three-folds greater than that of the negative controls (i.e., NA and P19).

\subsection{Plant-Expressed MAb and Rabies Virus- Neutralizing Activity}

The plant produced MAbs were purified by affinity chromatography. The purified antibodies were analyzed for their ability to neutralize rabies virus by RFFIT. In vitro comparison of the neutralizing activity of the plant MAb, and HRIG against cell culture-adapted CVS-11virus have indicated that plant MAb was active. The neutralizing potency of the plant affinity purified MAb was $2 \mathrm{IU} \cdot \mathrm{mL}^{-1}$.

\section{Discussion}

According to estimates by WHO, about 20 million people per year receive rabies PEP, which is almost invariably effective in preventing deaths from rabies
(4). Replacement of the universally used RIGs with an effective alternative such as MAbs is recommended for reasons of safety, availability, and cost (37). Many reports in recent years have indicated that MAbs can successfully be glycosylated and assembled in the plant cells $(38,39)$, such as rabies virus neutralizing MAb SO57 in transgenic tobacco $(13,19)$. However, the use of transient expression provides advantages of speed and simplicity of expression over stable transformation $(21,40)$.

The main objective of the present study was to demonstrate the feasibility of the transiently expressing human anti-rabies MAb SO57 using vacuum agroinfiltration of $N$. tabacum leaves. The first strategy to address this issue was the optimization of the gene sequences of the heavy and light chains. A recent report showed that plant codon optimization significantly increased the level of bovine papillomavirus (BPV) type $1 \mathrm{~L} 1$ production in comparison to the nonoptimized counterpart (41). We designed the synthetic genes reducing the GC content and increasing the CAI values to match with the tobacco's codon bias (42)(Fig. 2). However, the increase of the CAI value increases the $\mathrm{A}+\mathrm{T}$ content, which could decrease mRNA stability and exert a negative influence on the protein expression level. Therefore, optimization for plant codon bias does not always give the highest level of transgene expression $(43,44)$. For example, Šmídková et al. (45) have shown that plant optimization has little or no effect on transient expression of the human papillomavirus type 16 (HPV16) L1 gene.

Moreover, to enhance the expression efficiency, the Kozak consensus sequence (ACCAUGG) (29) was placed at the 5' end of the genes. To improve stability and increase the final yield of the transgene, the C-terminal KDEL sequence, an ER retention signal, (30) was attached to both antibody chains. Sriraman et al. (46) have shown that fusion of KDEL to the both chains of plantibody has resulted in a recombinant glycoprotein containing non-complex and nonimmunogenic glycans. It was demonstrated earlier that the expression level of human anti-rabies MAb SO57 increases by the addition of KDEL signal sequence to the heavy chain in transgenic tobacco (47).

The co-expression of RNA-silencing inhibitor protein, such as $\mathrm{p} 19$, suppresses post-transcriptional gene silencing, thereby enhancing both the level and the longevity of expression of the gene of interest in the transient expression (26). Mohammadzadeh et al. (48) have reported that co-infiltration of p19 could enhance the expression levels of plant-produced hepatitis $\mathrm{C}$ virus core protein ( $\mathrm{HCV} \mathrm{cp})$ up to about 5 -folds. The 
use of pCAMBIA1304 containing gus:gfp fusion vector allowed us to use the GFP as a visual marker for evaluation of the expressed genes located on T-DNA. The highest expression level of GFP was observed in the presence of p19 at 4 dpi.

The modified heavy and light chains' genes were cloned in the two pCAMBIA1304 vectors under the control of the CaMV 35S promoter (Fig. 1). The reports have indicated that the use of $35 \mathrm{~S}$ promoter from CaMV as a strong constitutive promoter positively influences the transgene expression (49). However, the expression of several genes under the control of one type of promoter could affect the expression level due to the employment of the same transcription machinery and/or homology-dependent gene silencing for the same promoter $(50,51)$. This pitfall could affect the expression of the assembled anti-rabies MAb SO57 in our study that is based on 3 similar promoters and other regulatory sequences. Although, higher expression of GFP in Li-pcambia construct co-agroinfiltrated with p19 showed that p19 could partially overcome this effect.

Finally, the presence of recombinant antibody chains in the tobacco plants was confirmed by anti-Fc and light chain antibodies in western blot analysis. The expected bands ( $\sim 25 \mathrm{kDa}$ and $\sim 50 \mathrm{kDa}$ ) (Fig. 5A) were visible in the crude protein extracts from agroinfiltrated leaves at 4 dpi compared to the extracts from non-infiltrated plants. The plant extracts transiently expressing antibody were analyzed and quantitated by ELISA. The results confirmed the efficient assembly of the heavy and light chains of the plantibody and its specific CVS-11 virus-binding activity (Fig. 6). The difference between the values of S1 and S2 samples is due to the fact that each transient expression experiment is an independent transformation event. The yield of the plant-made MAb (0.014 - $0.019 \%$ of TSP) was similar to that reported previously for HCVcp (48) using a similar method and higher than that reported for human growth hormone peptide ( $0.002 \%$ of TSP) (52). The higher yield obtained in our study compared to the latter report might be due to the codon optimization and/or co-agroinfiltration of the p19 silencing suppressor used in our approach.

Vaquero et al. (53) have shown that the level of expression in the transient transformants of the tobacco was 5 times higher than that of the transgenic tobacco plant. However, in our case, the level of expression was lower (i.e., $0.014-0.019 \%$ of TSP) compared to $0.07 \%$ as previously reported for the transgenic tobacco (13). We might attain higher levels of production using virus-based expression systems in addition to applying different promoters for each heavy and light chain $(54,55)$. Moreover, various factors can influence transient gene expression, including leaf position, OD of the infiltration and temperature after agro-infiltration $(56,57)$, and further enhancement of the transgene expression might be achieved by optimizing these factors. We also assayed the neutralizing activity of the assembled full-size MAb by the RFFIT method. The data have indicated that the protein-A affinity purified plantibodies were able to neutralize rabies virus activity in vitro with neutralizing potency of $2 \mathrm{IU} \cdot \mathrm{mL}^{-1}$. The use of optimized concentration protocol could enhance application of the plantibody for further experiments. In summary, the results of this study showed that the fully functional rabies virus neutralizing MAb SO57 was assembled and expressed transiently in tobacco leaves co-infiltrated with the p19 silencing suppressor in only 4 days after agroinfiltration. The human plantderived MAb was accumulated to $0.014-0.019 \%$ of TSP. These findings confirm that transient gene expression, as a rapid and efficient production system, could be used to produce the rabies virus antibody.

\section{Acknowledgement}

The work was supported by the Pasteur Institute of Iran, grant No 572. We are grateful to Dr. A. Jafari for her revision of the manuscript and Dr. A. H. Salmanian for his help regarding the gene optimization. We would like to thank Dr. A. Khabiri, Dr. Z. Noormohammadi, and Dr. S. Mohammadzadeh for their helpful comments and suggestions.

\section{References}

1. Finke S, Conzelmann K-K. Replication strategies of rabies virus. Virus Res. 2005;111(2):120-131. doi: 10.1016/j. virusres.2005.04.004

2. Yousaf MZ, Qasim M, Zia S, Khan M, Ashfaq UA, Khan S. Rabies molecular virology, diagnosis, prevention and treatment. Virol J. 2012;9:50. doi: 10.1186/1743-422X-9-50

3. Bakker A, Python C, Kissling C, Pandya P, Marissen W, Brink $\mathrm{M}$, et al. First administration to humans of a monoclonal antibody cocktail against rabies virus: safety, tolerability, and neutralizing activity. Vaccine. 2008;26(47):5922-5927. doi:10.1016/j.vaccine.2008.08.050

4. World Health Organization. WHO Expert Consultation on Rabies. Second report. World Health Organ Tech Rep Ser. 2013(982):1-139, back cover.

5. Marissen WE, Kramer RA, Rice A, Weldon WC, Niezgoda $\mathrm{M}$, Faber M, et al. Novel rabies virus-neutralizing epitope recognized by human monoclonal antibody: fine mapping and escape mutant analysis. J Virol. 2005;79(8):4672-4678. doi: 10.1128/JVI.79.8.4672-4678.2005

6. Bakker AB, Marissen WE, Kramer RA, Rice AB, Weldon WC, Niezgoda M, et al. Novel human monoclonal antibody combination effectively neutralizing natural rabies virus variants and individual in vitro escape mutants. J Virol. 2005;79(14):9062-9068. doi: 10.1128/JVI.79.14.9062- 
9068.2005

7. Ko K, Koprowski H. Plant biopharming of monoclonal antibodies. Virus Res. 2005;111(1):93-100. doi: 10.1016/j. virusres.2005.03.016

8. Müller T, Dietzschold B, Ertl H, Fooks AR, Freuling C, Fehlner-Gardiner C, et al. Development of a mouse monoclonal antibody cocktail for post-exposure rabies prophylaxis in humans. PLoS Negl Trop Dis. 2009;3(11):e542. doi: 10.1371/ journal.pntd.0000542

9. Prosniak M, Faber M, Hanlon CA, Rupprecht CE, Hooper DC, Dietzschold B. Development of a cocktail of recombinantexpressed human rabies virus-neutralizing monoclonal antibodies for postexposure prophylaxis of rabies. J Infect Dis. 2003;188(1):53-56. doi: 10.1086/375247

10. Yang L, Cen J, Xue Q, Li J, Bi Y, Sun L, et al. Identification of rabies virus mimotopes screened from a phage display peptide library with purified dog anti-rabies virus serum IgG. Virus Res. 2013;174(1):47-51. doi: 10.1016/j.virusres.2013.02.013

11. Frenzel A, Hust M, Schirrmann T. Expression of recombinant antibodies. Front Immunol. 2013;4:217. doi: 10.3389/ fimmu.2013.00217

12. Schillberg S, Fischer R, Emans N. Molecular farming of recombinant antibodies in plants. Cell Mol Life Sci. 2003;60(3):433-445. doi: 10.1007/s000180300037

13. Ko K, Tekoah Y, Rudd PM, Harvey DJ, Dwek RA, Spitsin $\mathrm{S}$, et al. Function and glycosylation of plant-derived antiviral monoclonal antibody. Proc Natl Acad Sci USA. 2003;100(13):8013-8018. doi: 10.1073/pnas.0832472100

14. De Wilde C, Peeters K, Jacobs A, Peck I, Depicker A. Expression of antibodies and Fab fragments in transgenic potato plants: a case study for bulk production in crop plants. Mol Breed. 2002;9(4):271-282. doi: 10.1023/A:1020306917914

15. Ehsani P, Meunier A, Nato F, Jafari A, Nato A, Lafaye P. Expression of anti human IL-4 and IL-6 scFvs in transgenic tobacco plants. Plant Mol Biol. 2003;52(1):17-29. doi: 10.1023/A:1023902407855

16. Schillberg S, Zimmermann S, Voss A, Fischer R. Apoplastic and cytosolic expression of full-size antibodies and antibody fragments in Nicotiana tabacum. Transgenic Res. 1999;8(4):255-263. doi: 10.1023/A:1008937011213

17. Perrin Y, Vaquero C, Gerrard I, Sack M, Drossard J, Stöger E, et al. Transgenic pea seeds as bioreactors for the production of a single-chain Fv fragment (scFV) antibody used in cancer diagnosis and therapy. Mol Breed. 2000;6(4):345-352. doi: 10.1023/A:1009657701588

18. Artsaenko O, Kettig B, Fiedler U, Conrad U, Düring K. Potato tubers as a biofactory for recombinant antibodies. Mol Breed. 1998;4(4):313-319. doi: 10.1023/A:1009676832273

19. Girard LS, Fabis MJ, Bastin M, Courtois D, Pétiard V, Koprowski $\mathrm{H}$. Expression of a human anti-rabies virus monoclonal antibody in tobacco cell culture. Biochem Biophys Res Commun. 2006;345(2):602-607. doi: 10.1016/j.bbrc.2006.03.219

20. Křenek P, Šamajová O, Luptovčiak I, Doskočilová A, Komis G, Šamaj J. Transient plant transformation mediated by Agrobacterium tumefaciens: Principles, methods and applications. Biotechnol Adv. 2015. doi: 10.1016/j. biotechadv.2015.03.012

21. Komarova TV, Baschieri S, Donini M, Marusic C, Benvenuto E, Dorokhov YL. Transient expression systems for plant-derived biopharmaceuticals. Expert Rev Vaccines. 2010;9(8):859-876. doi: 10.1586/erv.10.85

22. Hussein GM, Abu El-Heba GA, Abdou SM, Abdallah NA.
Optimization of transient gene expression system in Gerbera jemosonii petals. GM Crops Food. 2013;4(1):50-57. doi: 10.4161 /gmcr.23925

23. De Muynck B, Navarre C, Boutry M. Production of antibodies in plants: status after twenty years. Plant Biotech J. 2010;8(5):529563. doi: 10.1111/j.1467-7652.2009.00494.x

24. Both L, van Dolleweerd C, Wright E, Banyard AC, BulmerThomas B, Selden D, et al. Production, characterization, and antigen specificity of recombinant 62-71-3, a candidate monoclonal antibody for rabies prophylaxis in humans. FASEB J. 2013;27(5):2055-2065. doi: 10.1096/fj.12-219964

25. Rybicki EP. Plant-based vaccines against viruses. Virol J. 2014;11:205. doi: 10.1186/s12985-014-0205-0

26. Voinnet O, Rivas S, Mestre P, Baulcombe D. An enhanced transient expression system in plants based on suppression of gene silencing by the $\mathrm{p} 19$ protein of tomato bushy stunt virus. Plant J. 2003;33(5):949-956. doi:10.1046/j.1365313X.2003.01676.X

27. Mohammadzadeh S, Roohvand F, Memarnejadian A, Jafari A, Ajdary S, Salmanian A-H, et al. Co-expression of hepatitis C virus polytope-HBsAg and p19-silencing suppressor protein in tobacco leaves. Pharm Biol. 2015(ahead-of-print):1-9. doi: 10.3109/13880209.2015.1048371

28. Sheludko Y, Sindarovska Y, Gerasymenko I, Bannikova M, Kuchuk N. Comparison of several Nicotiana species as hosts for high-scale Agrobacterium-mediated transient expression. Biotechnol Bioeng. 2007;96(3):608. doi: 10.1002/bit.21075

29. Kozak M. Effects of intercistronic length on the efficiency of reinitiation by eucaryotic ribosomes. Mol Cell Biol. 1987;7(10):3438-3445. doi: 10.1128/MCB.7.10.3438

30. Munro S, Pelham HR. A C-terminal signal prevents secretion of luminal ER proteins. Cell. 1987;48(5):899-907. doi: 10.1016/0092-8674(87)90086-9

31. Sambrook J, Fritsch EF, Maniatis T. Molecular cloning: Cold Spring Harbor Laboratory Press. New York; 1989.

32. Holsters M, De Waele D, Depicker A, Messens E, Van Montagu M, Schell J. Transfection and transformation of Agrobacterium tumefaciens. Mol Gen Genet. 1978;163(2):181187. doi:10.1007/BF00267408

33. Kapila J, De Rycke R, Van Montagu M, Angenon G. An Agrobacterium-mediated transient gene expression system for intact leaves. Plant Sci. 1997;122(1):101-108. doi:10.1016/ S0168-9452(96)04541-4

34. Bradford MM. A rapid and sensitive method for the quantitation of microgram quantities of protein utilizing the principle of protein-dye binding. Anal Biochem. 1976;72(1):248-254. doi:10.1016/0003-2697(76)90527-3

35. Laemmli UK. Cleavage of structural proteins during the assembly of the head of bacteriophage T4. Nature. 1970;227(5259):680685. doi: 10.1038/227680a0

36. Meslin F, Kaplan M, Koprowski H. Laboratory Techniques in Rabies World Health Organization. Geneva, Switzerland. 1996.

37. Goudsmit J, Marissen WE, Weldon WC, Niezgoda M, Hanlon $\mathrm{CA}$, Rice $\mathrm{AB}$, et al. Comparison of an anti-rabies human monoclonal antibody combination with human polyclonal antirabies immune globulin. $J$ Infect Dis. 2006;193(6):796-801. doi: 10.1086/500470

38. Tekoah Y, Ko K, Koprowski H, Harvey DJ, Wormald MR, Dwek RA, et al. Controlled glycosylation of therapeutic antibodies in plants. Arch Biochem Biophys. 2004;426(2):266-278. doi: 10.1016/j.abb.2004.02.034

39. Komarova TV, Kosorukov VS, Frolova OY, Petrunia IV, 
Skrypnik KA, Gleba YY, et al. Plant-made trastuzumab (herceptin) inhibits HER2/Neu+ cell proliferation and retards tumor growth. PLoS One. 2011;6(3):e17541. doi: 10.1371/ journal.pone. 0017541

40. Sainsbury F, Sack M, Stadlmann J, Quendler H, Fischer R, Lomonossoff GP. Rapid transient production in plants by replicating and non-replicating vectors yields high quality functional anti-HIV antibody. PLoS One. 2010;5(11):e13976. doi: 10.1371/journal.pone.0013976

41. Love AJ, Chapman SN, Matic S, Noris E, Lomonossoff GP, Taliansky M. In planta production of a candidate vaccine against bovine papillomavirus type 1. Planta. 2012;236(4):1305-1313. doi: 10.1007/s00425-012-1692-0

42. Sharp PM, Li W-H. The codon adaptation index-a measure of directional synonymous codon usage bias, and its potential applications. Nucleic Acids Res. 1987;15(3):1281-1295. doi: 10.1093/nar/15.3.1281

43. Suo G, Chen B, Zhang J, Duan Z, He Z, Yao W, et al. Effects of codon modification on human BMP2 gene expression in tobacco plants. Plant Cell Rep. 2006;25(7):689-697. doi: 10.1007/s00299-006-0133-6

44. Maclean J, Koekemoer M, Olivier A, Stewart D, Hitzeroth I, Rademacher $\mathrm{T}$, et al. Optimization of human papillomavirus type 16 (HPV-16) L1 expression in plants: comparison of the suitability of different HPV-16 L1 gene variants and different cell-compartment localization. J Gen Virol. 2007;88(5):14601469. doi: 10.1099/vir.0.82718-0

45. Šmídková M, Müller M, Thönes N, Piuko K, Angelisová $\mathrm{P}$, Velemínský J, et al. Transient expression of human papillomavirus type 16 virus-like particles in tobacco and tomato using a tobacco rattle virus expression vector. Biol Plantarum. 2010;54(3):451-460. doi: 10.1007/s10535-010-0081-4

46. Sriraman R, Bardor M, Sack M, Vaquero C, Faye L, Fischer $\mathrm{R}$, et al. Recombinant anti-hCG antibodies retained in the endoplasmic reticulum of transformed plants lack corexylose and core- $\alpha(1,3)$-fucose residues. Plant Biotech J. 2004;2(4):279-287. doi: 10.1111/j.1467-7652.2004.00078.x

47. Lee J-H, Park D-Y, Lee K-J, Kim Y-K, So Y-K, Ryu J-S, et al. Intracellular reprogramming of expression, glycosylation, and function of a plant-derived antiviral therapeutic monoclonal antibody. PLoS One. 2013;8(8):e68772. doi: 10.1371/journal. pone. 0068772

48. Mohammadzadeh S, Khabiri A, Roohvand F, Memarnejadian A,
Salmanian AH, Ajdary S, et al. Enhanced-Transient Expression of Hepatitis C Virus Core Protein in Nicotiana tabacum, a Protein With Potential Clinical Applications. Hepat Mon. 2014;14(11):e20524. doi: 10.5812/hepatmon.20524

49. Ma JK, Drake PM, Christou P. The production of recombinant pharmaceutical proteins in plants. Nature Rev Genet. 2003;4(10):794-805. doi: 10.1038/nrg1177

50. Bhullar S, Chakravarthy S, Advani S, Datta S, Pental D, Burma PK. Strategies for development of functionally equivalent promoters with minimum sequence homology for transgene expression in plants: cis-elements in a novel DNA context versus domain swapping. Plant Physiol. 2003;132(2):988-998. doi: 10.1104/pp.103.020602

51. Charrier B, Scollan C, Ross S, Zubko E, Meyer P. CoSilencing of homologous transgenes in tobacco. Mol Breed. 2000;6(4):407-419. doi: 10.1023/A:1009672714835

52. Sohi HH, Jourabchi E, Khodabandeh M. Transient expression of human growth hormone in potato (Solanum tuberosum), tobacco (Nicotiana tobacum) and lettuce (Lactuca sativa) leaves by agroinfiltration. Iranian J Biotechnol. 2005;3(2):109.

53. Vaquero C, Sack M, Schuster F, Finnern R, Drossard J, Schumann D, et al. A carcinoembryonic antigen-specific diabody produced in tobacco. FASEB J. 2002;16(3):408-410. doi: 10.1096/fj.01-0363fje

54. Giritch A, Marillonnet S, Engler C, van Eldik G, Botterman J, Klimyuk V, et al. Rapid high-yield expression of full-size IgG antibodies in plants coinfected with noncompeting viral vectors. Proc Natl Acad Sci U S A. 2006;103(40):14701-14706. doi: 10.1073/pnas.0606631103

55. Huang Z, Phoolcharoen W, Lai H, Piensook K, Cardineau $\mathrm{G}$, Zeitlin L, et al. High-level rapid production of full-size monoclonal antibodies in plants by a single-vector DNA replicon system. Biotechnol Bioeng. 2010;106(1):9. doi: 10.1002/bit.22652

56. Leckie BM, Stewart Jr CN. Agroinfiltration as a technique for rapid assays for evaluating candidate insect resistance transgenes in plants. Plant Cell Rep. 2011;30(3):325-334. doi:10.1007/s00299-010-0961-2

57. Leuzinger K, Dent M, Hurtado J, Stahnke J, Lai H, Zhou X, et al. Efficient agroinfiltration of plants for high-level transient expression of recombinant proteins. J Vis Exp. 2013(77). doi: $10.3791 / 50521$ 